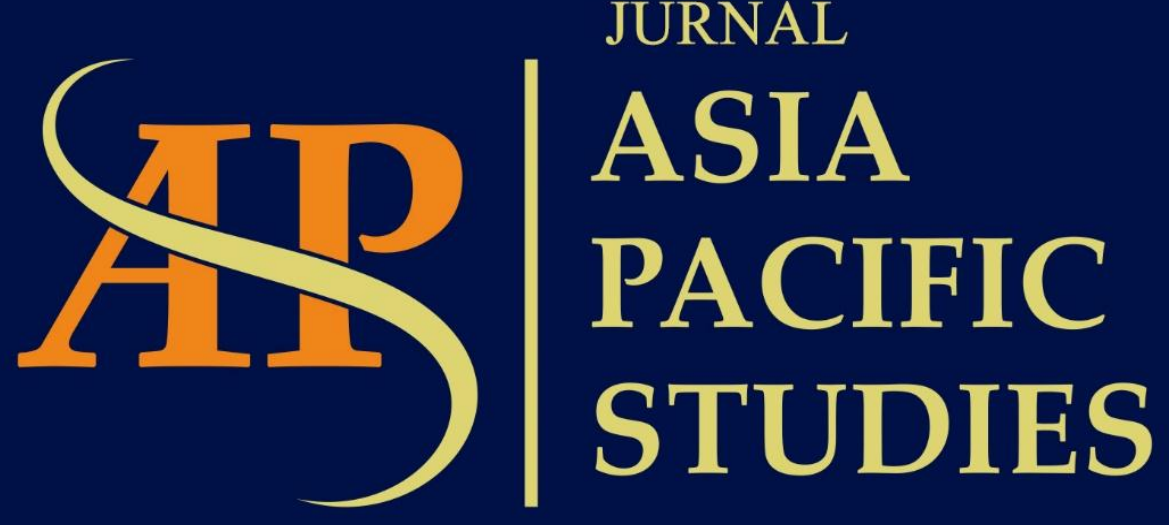

Journal of International Relations Study Program Faculty of Social and Political Sciences

Universitas Kristen Indonesia

Volume 2 | Number 2 | July - December 2018 


\title{
RIVALITAS GEOPOLITIK AMERIKA SERIKAT - TIONGKOK DI MYANMAR
}

\author{
${ }^{1}$ Eufronius Marianus Suwarman, ${ }^{2}$ Kartika Watunwotuk, ${ }^{3}$ Lecya Gaby Melianti, ${ }^{4}$ Maria Rosari, \\ ${ }^{5}$ Natalia Laurensia Carmelia Yewen, ${ }^{6}$ Regina Naomi \\ ${ }_{1,2,3,4,5,6}$ Hubungan Internasional, Fakultas Ilmu Sosial dan Ilmu Politik, Universitas Kristen Indonesia \\ 1efroneus.tamu@gmail.com, ${ }^{2}$ Kartikawatunwotuk17@gmail.com, ${ }^{3}$ Lecyagabymelianti98@gmail.com \\ ${ }^{4}$ mariarosari52@gmail.com, ${ }^{5}$ hobbinyewen@gmail.com, ${ }^{6}$ rgnaomi@yahoo.com
}

\begin{abstract}
The U.S.-China comprehensive competition is currently playing on an increasingly global scale. The main focus of competition is the vast Indo-Asia-Pacific region, which is centered in Southeast Asia, for example Myanmar. This writing will discuss the rivalries of the US and China in Myanmar to achieve their national interests. The method used in this writing is a qualitative method. The final argument from this paper is that the US-China rivalry is aimed at expanding their influence in Myanmar because the strategic region of Myanmar and abundant natural resources attract China. Beijing's profits are mostly economic and diplomatic, while Washington is more diverse. But Myanmar was able to respond well to the presence of these two great powers.
\end{abstract}

Key words: U.S - China Rivalry, US-China national interest, Myanmar response

\begin{abstract}
Abstrak
Kompetisi komprehensif A.S.-China saat ini bermain dalam skala yang semakin global. Fokus utama kompetisi adalah wilayah Indo-Asia-Pasifik yang luas, dan berpusat di Asia Tenggara, contohnya adalah Myanmar. Penulisan ini akan membahas rivalitas AS dan Tiongkok di Myanmar untuk mencapai kepentingan nasional mereka. Metode yang digunakan dalam penulisan ini adalah metode kualitatif. Argumen akhir dari penulisan ini bahwa rivalitas AS-Tiongkok ditujukan untuk memperluas pengaruh mereka di Myanmar karena wilayah Myanmar yang strategis dan sumber daya alam yang melimpah menjadi daya tarik Tiongkok. Keuntungan Beijing sebagian besar ekonomi dan diplomatik, sedangkan Washington lebih beragam. Namun Myanmar mampu menyikapi dengan baik kehadiran dua kekuatan besar tersebut.
\end{abstract}

Kata Kunci: Rivalitas AS-Tiongkok, Kepentingan nasional AS-Tiongkok, Respon Myanmar 


\section{Pendahuluan}

\subsection{Latar Belakang}

Myanmar terletak pada lokasi strategis yang menghadap Samudera Hindia dan juga satu-satunya pusat transportasi darat yang menghubungkan Asia Timur, Asia Tenggara, dan Asia Selatan. Lokasi Myanmar yang memiliki kepentingan geopolitik ini menjadikannya pusat perhatian bagi kekuatan utama dunia, di antaranya Cina, Amerika Serikat, India, Jepang, dan Uni Eropa.

Myanmar adalah negara yang telah menjadi sekutu utama Cina di Asia Tenggara dalam beberapa dekade terakhir. Di tengah proses reformasi Myanmar sejak 2011, negaranegara super power berusaha untuk meningkatkan hubungan dengan Myanmar dalam rangka mempromosikan kepentingan strategis mereka masing-masing. Secara strategis, kebijakan dan keterlibatan pragmatis AS di Myanmar terutama menggunakan Myanmar sebagai sarana untuk mengimplementasikan strategi pertahanan bagi Tiongkok dan India, sementara kepentingan ekonomi lebih rendah dalam agenda AS di Myanmar. Sebagai tetangga terbesar kedua di Myanmar, India telah kembali membangun hubungan geografis dan historisnya dengan Myanmar dalam rangka memanfaatkan Myanmar untuk stabilitas politik dan pembangunan ekonomi di negara-negara bagian timur lautnya.

Meskipun banyak kekuatan utama yang hadir di Myanmar dan mengambil keuntungan dari posisi strategis Myanmar, namun penulisan ini berfokus pada persaingan antara AS dan Tiongkok di Myanmar, sebab dua kekuatan ini terlihat jelas mendominasi persaingan diantara kekuatan lainnya. Amerika Serikat tampaknya terlalu sibuk dengan tantangan-tantangan khusus, yang paling menonjol diwakili oleh kebangkitan Republik Rakyat Tiongkok dan berada di garis depan, sangat ingin menggantikan peran sentral Amerika di kawasan ini, yang menempati kekosongan politik itu (Fiori \& Passeri 2015, 2).

\subsection{Rumusan Masalah}

a) Apa kepentingan dari AS-Tiongkok di wilayah Myanmar?

b) Bagaimana rivalitas antara AS-Tiongkok terjadi di Myanmar?

c) Bagaimana Myanmar menyikapi kehadiran dua kekuatan utama tersebut?

\subsection{Maksud dan Tujuan Penulisan}

Tujuan utama dalam penelitian ini adalah:

a) Mengetahui dan memahami rivalitas geopolitik Amerika Serikat dengan Tiongkok di Myanmar

b) Mengetahui apa saja kepentingan Amerika Serikat di Myanmar

c) Mengetahui apa saja kepentingan Tiongkok di Myanmar

d) Mengetahui bagaimana respon Myanmar terhadap rivalitas tersebut

\subsection{Manfaat Penelitian}

Manfaat penulisan penelitian ini adalah:

a) Penelitian ini diharapkan dapat memberikan sumbangan pemikiran untuk mengembangkan pemahaman terkait bagaimana hubungan Amerika Serikat dengan Tiongkok di Myanmar 
b) Penelitian sebagai sumbangsih untuk melengkapi hasil - hasil penelitian yang pernah ada terkait rivalitas geopolitik Amerika Serikat dengan Tiongkok di Myanmar.

\section{Kerangka Konseptual: Kepentingan Nasional}

Kepentingan Nasional adalah konsep utama dalam Hubungan Internasional. Semua bangsa selalu terlibat dalam proses memenuhi atau mengamankan tujuan kepentingan nasional mereka. Kebijakan luar negeri masing-masing negara dirumuskan berdasarkan kepentingan nasionalnya dan selalu bekerja untuk mengamankan tujuannya. Ini adalah hak yang diterima secara universal dari setiap negara untuk mengamankan kepentingan nasionalnya.

"The meaning of national interest is survival-the protection of physical, political and cultural identity against encroachments by other nation-states"-Morgenthau

Konsep Hans Morgenthau tentang "kepentingan nasional" pertama kali muncul dalam esai "The Primacy of the National Interest" sebagai bagian dari sebuah forum dalam edisi Musim Semi 1949 dari The American Scholar berjudul "Kepentingan Nasional dan Prinsip Moral dalam Kebijakan Luar Negeri. "Sebagaimana diamati oleh William Scheuerman" Konsep 'kepentingan nasional' pertama-tama mengambil status analitik khusus dalam esai ini. "Dalam esai, kepentingan nasional pertama kali disajikan sebagai korektif yang diperlukan untuk apa yang Morgenthau telah tandai dalam Scientific Man vs Power Politics sebagai legalisme, moralisme, dan sentimentalisme dalam politik Amerika, dan sebagai panduan yang lebih efektif untuk kebijakan luar negeri daripada yang tampaknya mampu diberikan oleh tradisi Amerika (Navari 2016).

Di dunia yang terdiri dari banyak negara yang bersaing dan menentang untuk mendapatkan kekuasaan, kelangsungan hidup mereka adalah syarat mutlak dan minimum mereka. "Dengan demikian semua negara melakukan apa yang tidak bisa tidak mereka lakukan: melindungi identitas fisik, politik, dan budaya mereka dari perambahan oleh negara lain. Sementara konsep kepentingan memang merupakan substansi politik dan, oleh karena itu, abadi dan tidak terpengaruh oleh waktu dan tempat. Selama dunia secara politis diorganisasikan ke dalam negara-negara, elemen penting dari kepentingan nasional, yaitu, kelangsungan hidup, adalah kata terakhir dalam politik dunia (Kiyonno 1969, 2-3). Kepentingan nasional dasardapat digambarkan sebagai berikut:

- $\quad$ Kepentingan pertahanan: perlindungan negara-bangsa dan warganya terhadap ancaman kekerasan fisik yang diarahkan dari negara lain, dan / atau ancaman yang diilhami secara eksternal terhadap sistem pemerintahannya.

- Kepentingan ekonomi: peningkatan kesejahteraan ekonomi negara-bangsa dalam hubungannya dengan negara-negara lain.

- Kepentingan Tatanan Dunia: pemeliharaan sistem politik dan ekonomi internasional di mana negara-bangsa dapat merasa aman, dan di mana warga dan perdagangannya dapat beroperasi secara damai di luar perbatasannya.

- $\quad$ Kepentingan ideologis: perlindungan dan kelanjutan dari seperangkat nilai yang dimiliki dan dipercayai oleh orang-orang dari negara-bangsa secara universal baik. 


\section{Pembahasan}

\subsection{Kepentingan Geoekonomi Tiongkok di Myanmar}

Asia merupakan wilayah yang penting bagi pengembangan ekonomi dan politik Tiongkok. Dari tahun 2008 total investasi Tiongkok di wilayah Asia mencapai 2.478.000 USD, dan jumlah ini terus bertambah dan meningkat hingga tahun 2015, dimana mencapai 5.884.000 USD, dan diperkirakan akan terus meningkat seiring dengan pembangunan di negara-negara Asia (Sucheng, 2015). Salah satu negara di Asia yang menjadi sasaran investasi dan target yang penting bagi pengembangan ekonomi Tiongkok ialah Myanmar. Tiongkok memiliki ikatan sejarah dan politik yang cukup penting dengan Myanmar, dengan begitu tidak heran bahwa kedua negara ini sering melakukan kerjasama khususnya di bidang ekonomi. Kerjasama yang terjadi ini juga dapat terjadi tentu saja karena Tiongkok memiliki kepentingan di Myanmar. Berikut ini merupakan beberapa kepentingan geoekonomi Tiongkok di Myanmar:

- Myanmar merupakan pasar yang besar bagi barang-barang Tiongkok

Tiongkok melihat Myanmar sebagai pasar yang besar bagi Tiongkok. Awalnya didorong oleh strategi "Go West" yang dimulai tahun 2002. Provinsi Yunnan di Tiongkok merupakan wilayah yang terdekat dengan Myanmar. Antara tahun 19962005, perdangangan perbatasan kedua wilayah ini menyumbang sekitar 55\% dari jumlah total nilai perdagangan Myanmar. Hal ini menjadikan Myanmar sebagai mitra dagang terbesar Yunnan (Myoe, 2007). Selain itu perdagangan antara Myanmar dan Tiongkok telah meningkat dalam beberapa tahun terakhir. Ekspor Tiongkok ke Myanmar naik 3,1 kali lebih banyak 261,2 juta USD pada 2001 menjadi 800,4 Juta USD pada 2007 (Kudo, 2008).

- Jalur baru untuk pengiriman minyak bagi Tiongkok

Sebelumnya 60-70\% pengiriman minyak untuk Tiongkok sangat mengandalkan Selat Malaka dan jalur ini dianggap tidak efisien (Alam, 2013). Maka dari itu, Tiongkok menginginkan apa yang dimiliki Myanmar, yaitu akses ke Samudra Hindia (Yonghong, 2014). Tiongkok membangun saluran langsung dari Tiongkok Barat Daya ke Samudra Hindia melalui Myanmar. Pada 2013, pipa gas Sino-Myanmar berhasil diselesaikan dan minyak mulai mengalir ke Tiongkok pada oktober 2013 (Yonghang, 2014).

- Sumber daya alam Myanmar Myanmar memiliki sumber daya alam yang kaya, seperti kayu, produk-produk dari sector pertanian dan perairan, serta buah-buahan (Yonghang, 2014).

- Kepentingan proyek Belt Road Initiative

Proyek jalur sutra Tiongkok ini dijalankan dengan melewati beberapa negara di Asia, dan Myanmar merupakan salah satu negara yang dilewati. Dengan begitu Tiongkok melakukan pendekatan-pendekatan dengan negara-negara tersebut, termasuk Myanmar agar proyek ini dapat berjalan (NN, 2016).

\subsection{Kepentingan Geopolitik AS di Myanmar}

Minat strategis utama Amerika Serikat di Tiongkok adalah untuk mengimplementasikan Strategi "penahanan ganda" baik Tiongkok dan India. Memang menilai dari hubungan ekonomi dan perdagangan saat ini antara Amerika Serikat dan 
Myanmar, kepentingan ekonomi bukanlah kepentingan inti yang mendorongnya mendekati atau terlibat secara pragmatis dengan Myanmar. Dengan demikian, tujuan strategis sesungguhnya adalah menggunakan Myanmar menahan Tiongkok dari timur dan mengekang India dari barat begitu untuk mempertahankan posisi dominan di Samudera Hindia. Sebagai "Bulan Sabit Luar" Amerika Serikat bermaksud mengandung kekuatan besar apa pun yang mengontrol "pinggiran" (Yonghong \& Hongchao, 2014, 2). Dunia telah berubah. Tiongkok telah bangkit. Amerika Serikat telah berputar kembali ke Asia Tenggara. Myanmar sekarang lebih mudah diakses dari segi politik dan ekonomi daripada selama 50 tahun terakhir (Jackson 2012, 2).

Amerika Serikat telah menggunakan strategi keterlibatan yang telah mengakui langkahlangkah positif yang dilakukan hingga saat ini dan untuk mendorong reformasi lebih lanjut. Prinsip-prinsip panduan dari pendekatan ini adalah mendukung reformasi politik dan ekonomi Burma; mempromosikan rekonsiliasi nasional; membangun transparansi pemerintah, dan akuntabilitas dan lembaga; memberdayakan komunitas lokal dan masyarakat sipil; mempromosikan keterlibatan internasional yang bertanggung jawab; dan memperkuat penghormatan dan perlindungan hak asasi manusia dan kebebasan beragama. Intensifitas kehadiran AS di Myanmar terjadi sejak pemerintahan Barack Obama. Pada saat kepemimpinannya, Obama telah melonggarkan sanksi terhadap Myanmar terkait hak asasi manusia dan meningkatkan kontak politik yang bertujuan untuk menahan kecenderungan Tiongkok dan Myanmar merupakan batu loncatan untuk meningkatkan hubungan yang lebih erat dengan ASEAN. Pada 2016, kedua negara meluncurkan Dialog Kemitraan AS-Myanmar, yang telah memperluas komunikasi dan kerja sama bilateral di bidang politik dan ekonomi. Berikut adalah berbagai kepentingan AS di Myanmar:

- Keamanan

Myanmar terletak di antara dua raksasa Asia, Tiongkok dan India yang sangat penting bagi kedua negara tersebut juga ASEAN. Tiongkok konsisten dalam memperluas pengaruhnya di Myanmar. Selama dekade sanksi yang diberikan AS, Tiongkok bertindak cepat menjadi sekutu diplomatik dan militer Myanmar, sumber bantuan keuangan, dan keahlian ekonomi.

\section{- Nilai-nilai}

Demokratisasi Myanmar telah menjadi tujuan kebijakan penting bagi semua pemerintahan AS baru-baru ini. sanksi saat ini diberlakukan terutama karena apa yang dilihat A.S. sebagai pengingkaran junta militer mantan penguasa atas hak asasi manusia dan kebebasan sipil rakyat.

\section{- Kemakmuran}

Banyak investor menggembar-gemborkan Myanmar sebagai Negara yang kaya akan permata, kayu, mineral, minyak dan cadangan gas alam lepas pantai, memiliki potensi yang belum dimanfaatkan secara signifikan. Ini juga menawarkan perusahaanperusahaan AS dalam jumlah setidaknya lebih besar dari Korea Selatan dan hampir tiga kali lipat Australia, meskipun bukan tanpa risiko investasi yang besar (Kuok 2014, 2-4). 


\subsection{Rivalitas AS - Tiongkok di Myanmar}

Tiongkok memandang Myanmar sebagai pasar besar untuk barang-barang Tiongkok. Hubungan Tiongkok dengan Myanmar sebagian besar didorong oleh strategi 'Go West' yang dimulai pada tahun 2000. Provinsi Yunnan di Tiongkok adalah wilayah terdekat dengan Myanmar. Antara tahun 1996 dan 2005, perdagangan perbatasan Myanmar-Yunnan menyumbang sekitar 55 persen dari total nilai perdagangan Myanmar,dan Myanmar adalah mitra dagang terbesar Yunnan.Perdagangan perbatasan China-Myanmar telah berkembang dalam beberapa tahun terakhir. Ekspor Cina meningkat 3,1 kali, dari US \$ 261,2 juta pada tahun 2001 menjadi US \$ 800,4 juta pada tahun 2007. Untuk 60-70 persen pengiriman minyaknya, Tiongkok sangat bergantung pada Selat Malaka, jalur air strategis yang menghubungkan Teluk Persia dengan Laut Cina Selatan. Demi keamanan dan keselamatan pengiriman minyaknya, Tiongkok telah meningkatkan kehadirannya di kawasan ini dengan mengembangkan hubungan diplomatik dan strategis khusus dengan negara-negara pesisir Samudra Hindia (Yonghong 2014, 16).

Sejak 1988, Tiongkok telah membantu pemerintah Myanmar membangun 8 dari 9 pabrik gula [US \$ 158 juta], 20 pembangkit listrik tenaga air [US \$ 269 juta], 13 dari 45 pabrik baru untuk Kementerian Perindustrian-1 [US \$ 198] juta], dan 12 dari 21 pabrik baru untuk Kementerian Perindustrian-2 [US \$ 137 juta]. Juga, Tiongkok meningkatkan 6 pabrik untuk Kementerian Perindustrian-2 [US \$ 346 juta], menyediakan 6 kapal pengangkut laut, dan membangun galangan kapal kering [US \$ 25 juta]. Pada tahun 2006, perusahaanperusahaan Tiongkok membangun tujuh dari sebelas pembangkit listrik tenaga air baru [US \$ 350-400 juta]. Analis intelijen sering mengatakan bahwa pengaruh ekonomi, politik dan militer Tiongkok di negara itu telah menjadi begitu kuat sehingga akan sulit bagi Yangon. untuk mengubah kebijakan luar negerinya secara radikal.

\section{- Bidang keamanan}

Myanmar adalah wilayah yang tepat untuk membendung pengaruh kekuatan besar lain ke Tiongkok dan ancaman ke Tiongkok. Tahun 2004, Tiongkok, melalui ekspansi ekonomi dan militer, membangun posisi yang memperkuatnya berhadapan dengan India dan Asia Tenggara, dan meningkatkan aksesnya ke Saluran Samudera Hindia. Oleh karena itu, Tiongkok tertarik untuk memanfaatkan Myanmar sebagai batu loncatan masa depan ke Samudra Hindia. Dengan demikian, masalah keamanan utama Tiongkok adalah menjaga Myanmar agar tidak menjadi bagian dari kebijakan" pengepungan Tiongkok "dari kebijakan AS.

\section{- Bidang Ekonomi}

Pengiriman energi maritim dari Teluk Persia ke Laut Cina Selatan tidak mencukupi, semakin dirusak oleh rasa tidak aman. dan fakta bahwa sekitar 80 persen impor minyak Tiongkok transit melalui "titik tersedak" Selat Malaka. Untuk mengatasi dilema ini, telah menjadi pilihan strategis bagi Tiongkok untuk membangun saluran langsung dari Tiongkok barat daya ke Samudra Hindia melalui Myanmar. Akibatnya, pada Juni 2013, pipa minyak dan gas Sino-Myanmar berhasil diselesaikan dengan gas mulai mengalir ke Tiongkok pada Oktober 2013. Selanjutnya, sumber daya alam Myanmar yang kaya (termasuk kayu, produk pertanian dan air, dan buahbuahan) dan ukuran pasar yang besar merupakan dorongan penting dan sangat diperlukan untuk pengembangan ekonomi Tiongkok serta menjadi tujuan penting untuk ekspor dan transfer industri Tiongkok. 
- Strategi AS di Myanmar

Tak lama setelah Presiden Obama terpilih kembali, beliau mengumumkan keinginannya untuk memimpin pertemuan puncak ekonomi tahunan internasional di Kamboja dengan berhenti di Thailand dan Myanmar. Perhentiannya di Myanmar adalah bersejarah karena tidak ada Presiden A.S. yang pernah mengunjungi Myanmar, negara yang terkenal otoriter. Sebelum pengumuman kunjungannya ke Myanmar, kunjungan Menteri Luar Negeri Hillary Rodham Clinton ke Myanmar merupakan perubahan dramatis dalam kebijakan terhadap Myanmar, pembukaan yang menunjukkan fokus baru A.S di Asia dengan membangun hubungan dengan negara penting yang secara strategis berbatasan dengan Tiongkok. AS juga ingin memperkuat hubungan dengan Myanmar dengan alasan bahwa kesenjangan hubungan antara AS dan Myanmar terlalu luas karena berbagai sanksi yang dijatuhkan oleh AS dan negaranegara Barat lainnya terhadap Myanmar dan Tiongkok, telah mengambil keuntungan dari ketidakhadiran negara-negara Barat yang berkepanjangan ini untuk melakukan konsolidasi. pijakan mereka di hampir semua sektor pemerintahan Myanmar.

Mengesampingkan pertimbangan geopolitik, Myanmar juga penting bagi A.S. dengan alasan tertentu. Skenario hak asasi manusia yang memburuk di Myanmar selalu menjadi yang terdepan dalam keprihatinan A.S. Satu-satunya keinginan Amerika adalah untuk mengalihkan kekuasaan dari rezim militer ke pemenang pemilu 1990. Ada juga potensi keruntuhan negara di Myanmar, yang pada gilirannya hanya akan menambah bahan bakar ke api dalam ketidakstabilan yang semakin memburuk.

Dengan kunjungan Obama ke Myanmar, pemerintah Myanmar berjanji akan membebaskan sekitar 1.600 tahanan politik, dan hingga November 2012, total 452 tahanan telah dibebaskan. Pengamat juga mengatakan bahwa kunjungan Presiden Obama akan mendorong Myanmar untuk tidak terlibat dalam perdagangan militer dan nuklir dengan Korea Utara. Perwakilan Khusus AS untuk Kebijakan Korea Utara Glyn Davies mengatakan: "Saya pikir Burma berada di jalan yang benar, bahwa mereka telah membuat keputusan strategis untuk secara fundamental mengubah hubungan mereka dengan DPRK dan pada akhirnya mengakhiri hubungan ini dengan Korea Utara. Setelah Sekretaris kunjungan Hillary Clinton ke Myanmar, Washington tampaknya telah menerima 'jaminan kuat' dari Presiden Thein Sein bahwa Myanmar akan bekerja sama dengan Badan Energi Atom Internasional (IAEA) dalam mematuhi Protokol Tambahannya. Setelah ditandatangani, instrumen ini akan membantu menyelesaikan AS dan kekhawatiran internasional tentang kemungkinan program nuklir Burma.

Menteri Luar Negeri AS Hillary Clinton menyatakan pada 14 November 2012, bahwa Presiden Barack Obama akan membahas kekerasan sektarian mematikan di Myanmar. Negara Rakhine antara Muslim Rohingya dan Buddha selama kunjungan bersejarahnya ke negara itu, dan Sekretaris Clinton mengatakan kerusuhan ini akan muncul dalam pembicaraan Obama.Akibatnya, Presiden Obama, dalam pidatonya di Universitas Yangon, mengatakan: "Hari ini, kami lihat kekerasan baru-baru ini di Negara Bagian Rakhine yang telah menyebabkan begitu banyak penderitaan, dan kita melihat bahaya dari ketegangan yang berkelanjutan di sana. Sudah terlalu lama, orangorang di negara bagian ini, termasuk etnis Rakhines, menghadapi kemiskinan yang parah dan penganiayaan. Tetapi tidak ada alasan untuk kekerasan terhadap orang yang tidak bersalah. Dan Rohingya mempertahankan diri mereka - berpegang pada diri mereka sendiri - dengan martabat yang sama seperti Anda, dan saya juga.

Pemerintahan Obama telah melonggarkan sanksi terhadap Myanmar, meningkatkan kontak politik, dan menyetujui dan bahkan mendorong hubungan lebih 
dekat India dengan Myanmar. Tujuannya adalah untuk memberi Myanmar opsi yang lebih strategis tanpa kecenderungan berlebihan pada Cina untuk menjaga "keseimbangan kekuasaan" di kawasan Asia-Pasifik. Selain itu, Myanmar juga berfungsi sebagai batu loncatan untuk mengembangkan hubungan yang lebih erat dan kerja sama dengan ASEAN sehingga dapat menahan Cina. Dalam konteks kebangkitan China sebagai kekuatan besar dan hubungan yang semakin dalam dengan Asia Tenggara, "AS telah berupaya untuk menangkal dan mengimbangi ofensif pesona China di Asia Tenggara, serta menghadapi ketegasan China yang meningkat di kawasan tersebut pada masalah-masalah seperti Laut Cina Selatan.

Tujuan lain Amerika Serikat adalah untuk mempromosikan nilai-nilai kebebasan dan demokrasi di Myanmar. Sementara sanksi selama beberapa dekade telah mengucilkan Myanmar, proses reformasi (dengan Aung San Suu Kyi memainkan peran yang semakin meningkat) memberi Amerika Serikat peluang untuk menarik Myanmar ke dalam "busur kebebasan dan demokrasi dan kemakmuran." tujuan strategis untuk menahan Tiongkok dengan mempromosikan rezim demokratis di perbatasannya, yang melayani tujuan mengisolasi Cina dan berusaha mempromosikan demokratisasi.

Sementara sampai sekarang Ekonomi menjadi prioritas kedua, Amerika Serikat juga ingin membuka pasar Myanmar untuk memperoleh bagian lebih besar dari sumber daya dan energi Myanmar. Konsorsium bisnis besar Amerika mengeluh tentang kebijakan pemerintah yang keras terhadap Myanmar yang telah mencegah mereka menuai keuntungan di negara itu. Selama tiga dekade terakhir, Cina telah mendominasi perdagangan dan investasi asing di Myanmar, dan, dalam beberapa tahun terakhir, India dan Jepang juga telah memperkuat kehadiran ekonomi mereka di Myanmar.Melihat kondisi ini memicu Amerika Serikat untuk meningkatkan kehadirannya di Myanmar dengan meningkatkan bantuan, perdagangan, dan investasi.

\subsection{Sikap Myanmar Terhadap Rivalitas AS - Tiongkok di Wilayahnya}

Kehadiran kekuatan besar di Myanmar bukan saja Amerika Serikat dan Tiongkok, melainkan Jepang, India, dan Organisasi supranasional yaitu Uni Eropa. Kelima kekuatan utama ini hadir dinegara tersebut untuk mengejar kepentingan mereka, namun artikel ini akan berfokus pada kehadiran Amerika Serikat dan Tiongkok di Myanmar dan bagaimana Myanmar menyikapi kehadiran dua kekuatan utama tersebut.

Myanmar bukan sekadar pion yang terperangkap dalam pertandingan antara kekuatankekuatan utama itu, tetapi juga jelas memiliki kepentingan dan pertimbangannya sendiri, paling tidak dalam upaya untuk menyeimbangkan kepentingan yang bersaing dari kekuatan eksternal. Dalam hal keamanan, Myanmar bermaksud untuk memaksimalkan kemandiriannya, diantara Amerika Serikat dan Tiongkok Myanmar tidak memihak kepada salah satunya. Oleh karena itu, Myanmar ingin memiliki hubungan baik dengan semua negara, sementara pada saat yang sama mencegah satu kekuatan mendapatkan keuntungan luar biasa, yang dengan demikian dapat mendominasi kebijakan dalam negeri dan luar negeri Myanmar. Sejak 2010, para pemimpin negara Myanmar telah sering mengunjungi Tiongkok, Amerika Serikat, India, dan Uni Eropa untuk menunjukkan diplomasi yang fleksibel. Dengan melakukan hal itu, pemerintah Myanmar sengaja berusaha menyeimbangkan aktor eksternal yang berbeda satu sama lain untuk meminimalkan tekanan eksternal dan memaksimalkan konsesi. Myanmar berupaya untuk menormalkan hubungan dan meningkatkan kerja sama dengan kedua kekuatan yaitu AS dan Tiongkok. AS dipandang sebagai negara adikuasa yang tidak dapat diabaikan dan yang dapat membantu Myanmar memasuki kembali komunitas 
internasional. Presiden U Thein Sein mengatakan selama kunjungannya ke Amerika Serikat pada Mei 2013, "Myanmar berkomitmen untuk mempromosikan reformasi politik dan ekonomi serta persatuan nasional [dan] meminta perusahaan-perusahaan AS untuk berinvestasi di Myanmar. "Dengan demikian, akan lebih baik bagi perkembangan ekonomi dan modernisasi Myanmar jika terbuka bagi perusahaan-perusahaan AS dan memungkinkan aliran modal, sementara Myanmar mengejar kepentingan ekonomi dalam hubungannya dengan kekuatan lain untuk mencapai modernisasi dan pembangunan ekonomi yang cepat. Oleh karena itu, Myanmar menyambut perusahaan Cina untuk berinvestasi dalam pembangunan saluran energi China-Myanmar dan "koridor ekonomi BCIM (BanladeshChina-India-Myanmar) (Dai 2014, 17-18).

Hubungan Myanmar dengan Tiongkok terutama didasarkan pada persamaan kekuatan asimetris, yang terbukti bermanfaat bagi Myanmar, setidaknya dalam jangka pendek. Kedua, negara tersebut bercita-cita untuk mendapatkan manfaat dari proyek infrastruktur dan energi Tiongkok (termasuk Zona Ekonomi Eksklusif Kyaukpyu dan jaringan pipa minyak dan gas atau, baru-baru ini, Koridor Ekonomi China-Myanmar yang banyak dibahas), terutama karena investasi Tiongkok tidak membawa prasyarat apa pun tentang hak asasi manusia atau prinsip demokrasi. Oleh karena itu, Myanmar akan terus mempertahankan Pauk Phaw (hubungan persaudaraan) dengan Tiongkok bahkan ketika kompetisi AS-Tiongkok memanas. Ini sebenarnya melayani kebijakan luar negeri Myanmar yang telah lama dipegang, yang menyerukan untuk menyeimbangkan faktor-faktor internal sambil mengelola hubungan eksternal secara independen (Kundu 2018).

Mengetahui ekonomi Tiongkok yang semakin kuat, Dalam kunjungannya ke China tahun 2016, Aung San Suu Kyi menyatakan bahwa Myanmar menyambut inisiatif One Belt, One Road (sekarang dikenal Belt and Road Initiative), dan kerja sama seluruh Koridor Ekonomi Bangladesh-Cina-India-Myanmar. Kedua negara sepakat untuk meningkatkan kerja sama ekonomi mereka, tetapi keputusan tentang mega-proyek kontroversial Tiongkok, terutama proyek bendungan Myitsone dan Salween, ditunda hingga pemerintah Myanmar yang baru dapat sepenuhnya menilai dampak lingkungan dan sosial mereka serta perjanjian pembagian sumber daya (Murphy 2016).

AS dan Tiongkok memiliki banyak hal untuk ditawarkan kawasan ini dalam hal bantuan pembangunan dan investasi perusahaan - jika masing-masing negara menyatakan tujuan dalam G20 dan EAS (East Asia Summit) tetap berlaku, negara-negara Asia Tenggara, terutama Myanmar, akan mendapat manfaat besar. Strategi menyeluruh Belt and Road Initiative dan Pivot to Asia hanya akan berhasil jika mereka mempertimbangkan keprihatinan, tujuan pembangunan, dan keinginan negara-negara yang menjadi tujuan dan dampaknya. Seperti yang sudah jelas terlihat di Myanmar, negara-negara di kawasan itu tidak lagi berhasrat untuk digadaikan dalam permainan ekonomi geopolitik, tetapi lebih merupakan mitra yang aktif dan kolaboratif untuk memastikan manfaat yang adil bagi semua — sebagai lawan dari hasil nol total yang paling lazim di masa lalu.

\section{Kesimpulan}

Myanmar terletak di persimpangan Asia Selatan dan Tenggara. Ini terhubung ke India dan Tiongkok di perbatasan barat laut dan timur laut masing-masing. Selain itu, cadangan sumber daya energinya, kelas konsumen yang baru muncul, populasi yang muda, dan aksesnya ke Teluk Bengal dan Samudra Hindia menjadikannya pemangku kepentingan penting di kawasan Asia-Pasifik (dan Indo-Pasifik). Myanmar telah terlibat dalam diskusi kebijakan luar negeri sebagian besar tetangganya, termasuk Tiongkok, India, dan negaranegara Perhimpunan Bangsa Bangsa Asia Tenggara (ASEAN). Ini juga menjadi faktor dalam 
kebijakan "pivot to Asia" Amerika Serikat pada masa pemerintahan mantan Presiden Barack Obama. Bagi AS, Myanmar penting sebagai jalan lain untuk mengurangi pengaruh dan dominasi yang dinikmati oleh Tiongkok di kawasan itu.

Hubungan Myanmar dengan Tiongkok terutama didasarkan pada persamaan kekuatan asimetris, yang terbukti bermanfaat bagi Myanmar, setidaknya dalam jangka pendek. Sementara itu, perbaikan dalam hubungan AS-Myanmar pada kuartal pertama 2010 adalah hasil dari perubahan geopolitik di Asia-Pasifik, yang memungkinkan Myanmar untuk memilih keseimbangan dalam hubungan eksternal (dan kadang-kadang, bahkan lindung nilai ringan) dengan Tiongkok.

Tiongkok melihat Myanmar sebagai pasar yang besar bagi Tiongkok, posisi Myanmar yang strategis menjadi peluang melancarkan segala kepentingan Tiongkok termasuk kebijakan yang sedang digadang-gadnag yaitu Belt Road Initiative, sedangkan AS melihat Myanmar yang stategis untuk membendung kebangkitan kekuatan Tiongkok di negara itu dan mendukung kemajuan demokrasi di Myanmar serta tidak menutup kemungkinan untuk menanamkan investasi dari perusahaan-perusahaan besar AS di Myanmar.

Rivalitas antara AS-Tiongkok tidak membuat Myanmar tenggelam dalam kegelisahan dan dilemma, justru negara ini mengambil keuntungan dengan hadirnya dua kekuatan besar tersebut yang paling dominan. Myanmar tidak berpihak ke salah satu kekuatan, melainkan membuka hubungan baik dengan AS maupun Tiongkok. Kerjasama ekonomi pembangunan jalur pipa dan minyak antara Tiongkok dan Myanmar terus terjalin, namun Myanmar tidak membiarkan Tiongkok mendominasi wilayahnya, dengan menerapkan system lindung nilai dan tetap membutuhkan AS untuk menyeimbangi kehadiran Tiongkok 


\section{DAFTAR PUSTAKA}

\section{Buku}

Alam, Ishtiaque. 2013. "Rising Myanmar: US involvement, power rivalry and new hopes for Bangladesh." Croatian International Relations Review 46.

Kudo, T. 2008. Myanmar's Economic Relations with China: Who Benefits and Who Pays? in Monique Skidmore and Trevor Wilson (eds.) Dictatorship, Disorder and Decline in Myanmar. Canberra: Australian National University.

Myoe, M.A. 2007. "Sino-Myanmar economic relations since 1988." Asia Research Institute Working Paper, No. 86. Accessed Juni 8, 2019. www.ari.nus.edu.sg/showfile.asp?pubid=647\&type $=2$.

Sucheng, Liu. 2015. China and New World Economy. London: Palgrave Mc Millan.

\section{Dokumen Online}

Yonghong, Dai. 2014. Rivalry and Cooperation: A New "Great Game" in Myanmar. Singapura: Stallion Press.

http://isdp.eu/content/uploads/images/stories/isdp-main-pdf/2014-yonghong-rivalryand-cooperation-a-new-great-game-in-myanmar.pdf

\section{Koran Online}

Kundu, Sampa. "How Myanmar Benefits from the US-China Competition in the Indo Pacific". The Diplomat. Desember 08, 2018. Diakses pada 06 Juni 2019. https://thediplomat.com/2018/12/how-myanmar-benefits-from-the-us-china competition-in-the-indo-pacific/

\section{Report}

Jackson, Karl D. Myanmar Awekening and U.S National Interests. Washington D.C: C.V. Starr Distinguished Professor of Southeast Asian Studies. 2012. Diakses pada 14 Juni 2019. http://web.jhu.edu/administration/gca/_archive/legacyassets/MyanmartestimonyApril2012.pdf

Kuok,Lynn. Promoting Peace In Myanmar U.S Interests and Role. Lanham: Rowman \& Littlefield. 2014. Diakses pada 14 Juni 2019. https://csis-prod.s3.amazonaws.com/s3fs public/legacy_files/files/publication/140428_Kuok_PeaceMyanmar_Web.pdf

\section{Artikel dalam Jurnal Online}

Kiyonno, Ken. 1969. "A Study on the Concept of The National Interest of Hans J. Morgenthau: as The Standard of American Foreign Policy". NAOSITE 49: 1-20. http://naosite.lb.nagasaki- u.ac.jp/dspace/bitstream/10069/27783/1/keieikeizai49_03_04.pdf 


\section{Website}

Murphy, Erin. "Myanmar: Capturing the Essence of U.S. and Chinese Policy Priorities". Chinausfocus. Sep 12, 2016. Diakses pada 07 Juni 2019. https://www.chinausfocus.com/foreign-policy/myanmar-capturing-the-essence-of-u-s and-chinese-policy-priorities

Navari, Cornelia. "Hans Morgenthau and the National Interest. EIA. Maret 2016. Diakses pada 16 Juni 2019. https://www.ethicsandinternationalaffairs.org/2016/hans-morgenthau and-the-national-interest/

United States. Bureau of East Asian Pacific Affairs. U.S Relations with Burma. Washington DC: U.S Department of State. 2018. https://www.state.gov/u-s-relations-with-burma/ 